\title{
Kırgızistan'da Ticari Bankaların Maliyet Etkinliğini Etkileyen Faktörler
}

Dastan ASEiNOV

Makale Gönderim Tarihi: 06.11.2018

Makale Kabul Tarihi: 12.09.2019

\section{Öz}

Ticari bankaların etkinliği hem onların sahipleri ve yöneticileri, hem de düzenleyici ve denetleyici otoriteler için önemli sorunlardandır. Bu çalıșmanın amacı, Kırgız bankalarının maliyet etkinliliğini etkileyen faktörleri araștırmaktır. 2000-2013 dönemindeki 23 Kırgız ticari bankayı kapsayan dengesiz panel veri seti kullanarak Battese ve Coelli'nin (1995) önerdiği stokastik maliyet sınır modeli tahmin edilmiștir. Elde edilen sonuçlar bankacılık maliyet etkinliliğini daha çok ölçüde kapitalizasyonun, yabancı mülkiyetin, kredi riskinin, likidite riskinin ve kur riskinin etkilediğini göstermektedir. Maliyet etkinliğindeki değișimler, bankaların risk alma davranıșlarının düzenleyici ve gözetim otoritelerince izlenmesinde bir gösterge olarak kullanılabilir.

Anahtar Kelimeler: bankacılık, stokastik sınır analizi, geçiș ekonomileri, maliyet etkinliği

JEL Sınıflandırması: C30, G21, D24

\section{Factors Affecting Cost Efficiency of Commercial Banks in Kyrgyzstan}

\section{Abstract}

Efficiency of commercial banks is among important challenges not only for their shareholders and managers, but also for regulation and supervision authorities. The aim of this study is to examine factors affecting the banking cost efficiency for Kyrgyz banks. We estimate

Araștırma Görevlisi, Dr, Finans ve Bankacılık Bölümü, İktisadi ve İdari Bilimler Fakültesi, Kırgızistan - Türkiye Manas Üniversitesi, Bișkek, Kırgızistan, dastan.aseinov@gmail.com, http://orcid.org/0000-0001-9264-1419 
stochastic cost frontier model proposed by Battese and Coelli (1995) using unbalanced panel data set captured 23 Kyrgyz commercial banks for period of 2000-2013. Obtained results suggest that capitalization, foreign ownership, credit risk, liquidity risk and currency risk have most influence on banking cost efficiency. Cost efficiency scores can be used as an indicator for monitoring of risk-taking behavior of commercial banks by regulatory and supervisory authorities.

Keywords: banking, stochastic frontier analysis, transition economies, cost efficiency

JEL Classification: C30, G21, D24

\section{Giriș}

Çoğu ülkelerde finansal sistemin önemli kısmını bankacılık sektörü olușturmaktadır. Dolayısıyla, ilgili literatürde ekonomik büyüme açısından bankacılık kurumlarının etkinliğinin önemli bir yere sahip olduğuna dair fikir birliği olușmuștur (Seven ve Yetkiner, 2016; Xu, 2016). Geçiș ve gelișmiș ekonomilerdeki bankacılık sektörleri birbirinden farklılık göstermektedir. Geçiș ekonomileri arasından eski Sovyetler Cumhuriyetlerinin bankacılık sistemleri 1990'lardaki geçiș döneminde ağır bir siyasi, sosyal ve iktisadi șartlarda bulunmușlardır. Bu șartlardan dolayı geçiș ekonomilerindeki bankalar kendi fonksiyonlarını yeterli ölçüde yerine getirememișlerdir. (Bonin ve Wachtel, 2003; Bonin vd., 2005). Bu ülkelerden biri olan Kırgızistan bankacılık sisteminin temel fonksiyonu finansal istikrarın sağlanması doğrultusunda finansal aracılık faaliyetini gerçekleștirmektir. 2000'lerde șartların iyileșmesi sonucunda bazı eski Soviyet ülkelerinin bankacılık sistemleri gelișim gösterebilmiștir. Fakat, Kırgızistan'ın bankacılık sisteminin diğer geçiș ekonomileri bankacılık sistemlerine kıyasla daha az bașarıyla gerçekleștirdiği görülmektedir. 2017 yılı itibariyle Kırgızistan bankacılık sektörünün toplam aktiflerinin, toplam kredilerinin ve toplam mevduatlarının GSYiH'ya oranı sırasıyla \%38; \%20.8 ve \%23.3 olduğu göz önüne alınırsa, bu sektörün etkinliği ülke ekonomisinin gelișmesi açısından önem tașımaktadır (National Bank of the Kyrgyz Republic [NBKR], 2018:49).

Kırgızistan'daki ekonomik değișimler, finansal ve bankacılık sisteminin dönüșümü eșliğinde gerçekleșmiștir. Bankacılık sektöründeki temel değișimler kapsamında iki katmanlı bankacılık sisteminin olușturulması, bankaların uluslararası muhasebe standartlarına geçiș ve ihtiyati düzen- 
lemelerin belirlenmesi öngörülmüștür. 1990'lardaki iktisadi ve finansal sorunların piyasa ekonomisi șartlarına ve ilkelerine uygun bir șekildeki çözümü gerekiyordu. Bu doğrultuda kendilerine önemli rol ayrılmıș olan o dönemin ticari bankaları, eskiden devlet tarafından sağlanan önemli desteklerden yoksun bırakılmıș kamu bankalarının özelleștirilmesiyle kurulmuștur.

Kırgızistan'ın finansal sisteminin ve finansal aracılığın en büyük kısmını kapsayan ve gerçekleștiren bankacılık sektöründeki istikrarsızlıklar ülke ekonomisini olumsuz yönde etkilemiștir. 1990'ların bașında geçiș ekonomilerinin bankacılık sistemlerinde ortaya çıkan sorunlu krediler istikrarsızlıklara neden olarak bankacılık sisteminin etkinsizliğine yol açmıștır (Gorton and Winton, 1998:646). 1990'ların ikinci yarısında, 1998 yılındaki Rusya krizi ve kurumsal istikrarsızlıklar, 2005 ve 2010'deki siyasi sorunlar olumsuz etkisi sonucunda Kırgızistan'daki bankaların iflasları, bankacılık sistemine olan güveni azaltmıștır (Kloc, 2001; Bektenova ve Atabayev, 2012:29; Ruziev ve Majidov, 2013). Bunun yanısıra, bölgedeki diğer ülkelerden kaynaklanan dıșsal șoklar ülkenin bankacılık sektörünü olumsuz etkilemiștir (Aseinov \& Karymshakov, 2018).

Bu șartlarda bankaların finansal sağlamlığı önem arz etmektedir. Bankaların ekonomik durumunun hatalı, eksik, ve çoğu kez güvenilirliği düșük yollarla değerlendirilmesi, küresel ekonomik krizin ortaya çıkıș nedenlerinden olduğu görülmüștür (Alantar, 2008). Çoğu durumlarda bankaların finansal ve iktisadi sağlamlığının ve güvenliğinin bir göstergesi olarak da bankanın karlılığı ele alınmaktadır. Karlılığı doğrudan etkileyen önemli belirleyici de maliyetlerdir. Aynı zamanda, bankacılık maliyetleri mevcut koșullar altında banka sahipleri ve yöneticileri tarafından alınan kararların etkinliğinin bir göstergesidir. İșü̈cü, sermaye ve fonlar gibi girdilerin etkin kullanımı; ayrıca, maliyetleri arttıran risklerin daha bașarılı yönetimi ile bankaların iktisadi ve mali durumlarının güçlendirilmesi bankacılık sisteminin istikrarlı gelișmesini sağlayabilir. Dolayısıyla, büyük bir kısmı bankalardan olușan Kırgızistan'ın finansal sektöründeki istikrarın sağlanmasında bankaların iktisadi etkinliği önemlidir.

Dıșsal faktörleri etkileyerek bankacılık sektöründe gerçekleștirilen deregülasyonun amacı maliyetleri minimize edilmesi, kaynakların etkin kullanılması ve kalitenin arttırılmasına yöneliktir (Goddard vd., 2014). Bundan hareketle, bankaların etkinliklerindeki farklılıkların analizi hem bankaların hem de genel politika çıkarımları yapan taraflar için önem- 
lidir (Kök ve Deliktaș, 2003:46). Bankacılık faaliyetinin etkinliği esas alınarak elde edilen araștırma sonuçları ve bulgular, düzenleyici ve gözetim otoriteleri tarafından bankacılık sektörüne yönelik politika geliștirilmesinde kullanılabilir bilginin birikimine katkı sağlar. Bu açıdan ele alındığında Kırgızistan bankacılık sektöründeki bankaların finansal aracılık faaliyetindeki maliyet etkinliğini etkileyen etkenlerin araștıılması önem tașımaktadır.

Bu çalıșmanın amacı bankaların risk alma eğilimi, büyüklük, sahiplik yapısı, dıșsal çevre gibi etkenlerin bankaların maliyet etkinliği üzerindeki etkisini incelenmektir. Bunun yanısıra, Kırgızistan'daki ticari bankaların Stokastik Sınır Yaklașımı ile maliyet etkinliğinin ölçülmesin de imkan sağlayan Battese ve Coelli (1995) tarafından önerilen modelin uygulanması amaçlanmıștır.

Çalıșma altı bölümden olușmaktadır. Çalıșmanın sonraki bölümde Kırgızistan bankacılık sektörünün etkinliği ile ilgili yazındaki çalıșmalar incelenmiștir. Üçüncü bölümünde bankaların etkinliğinin analizi için uygulanan Stokastik Sınır Yaklașımı (bundan sonra, SSY) yöntemi ve bu yöntem kapsamında uygulanan model açıklanmıștır. Çalıșmanın dördüncü bölümünde tahmin edilen modelde kullanılan değișkenler ve veri seti betimlenmiștir. Son bölümlerinde analiz sonuçları ve elde edilen ampirik bulgular yorumlanarak çalıșma sonuçlandırılmıștır.

\section{Literatür}

Bankacılık kurumlarının etkinliğinin ölçülmesinde "sınır" yaklașımlarından biri olan Veri Zarflama Analizi ilk kez Sherman ve Gold (1985) tarafından uygulanmıștır. SSY'nın banka verilerine ilk kez uygulanması ise Ferrier ve Lovell (1990) tarafından gerçekleștirilerek maliyet etkinliği ölçülmüștür. Bu çalıșmayı izleyen Berger ve Humphrey (1992)'in çalıșmasında da maliyet etkinliği ölçülmüștür. Berger vd. (1993)'in çalıșmasında ise ilk kez bankaların kar etkinliği SSY'nın uygulanarak analiz edilmiștir. Söz konusu çalıșmalarda ABD bankaları verileri kullanılmıștır. Sonraki yıllarda farklı ülkelerin bankalarına ait verilere SSY uygulanan çalıșmaların büyük bir akını bașlamıștır. Berger ve Humphrey (1997)'in çalıșmasında 21 ülkenin finansal kurumlarına uygulanmıș 130 çalıșma incelenmiștir. 1990'larda etkin sınır yaklașımı ile bankacılık etkinliğini araștıran çalıșmaların sayısında hızlı bir artıș yașanmıștır. Bunun sonucunda günümüzde bankacılık etkinliği analizlerini kapsayan çalıșmalar çok geniș bir literatürü ortaya çıkartmıștır. 
Bu çalıșmada uygulanan SSY, 1990'lardan sonraki dönemlerde farklı ülkelerin bankacılık sektörleri için yoğun uygulanan yöntemlerden biridir. Buna rağmen, eski Sovyetler cumhuriyeti geçiș ekonomilerinde SSY uygulanan çalıșmaların sayısı sınırlı olduğu görülmektedir. Sovyet blokundan ortaya çıkan BDT, Doğu Avrupa, Baltık ülkelerinin bankacılık sektörleri üzerine SSY uygulanan çalıșmalar mevcuttur (Mertens ve Urga, 2001; Grigorian ve Manole, 2002; Kasman ve Yıldırım, 2006; Maslak ve Buryak, 2009; Delis vd., 2011 ; Kumar ve Gulati, 2014; Dialilov ve Piesse, 2014; Mamonov, 2013; Glass vd., 2014). Fakat, geçiș ekonomilerindeki bankaların etkinliğini konu alan bu çalıșmalarda Kırgızistan bankaları dahil edilmemiștir. Bunun bașlıca nedeni Bankscope ve diğer benzeri veri tabanlarında Kırgızistan bankalarına ait verilerin eksik olmasıdır. Bu çalıșmada ise, bankalar tarafından resmi sitelerde yayınlanmıș finansal raporlardan temin edilen bilgiler ile olușturulmuș özgün panel veri seti kullanılmıștır.

Yazında Kırgızistan'daki bankacılık kurumlarının etkinliği üzerine yapılan bazı çalıșmalar mevcuttur. Fakat, bu çalıșmalarda bankaların etkinliğinin analizinde daha çok Veri Zarflama Analizi (Keleș, 2011; Dialilov ve Piesse, 2011; Cheng vd., 2013) ve finansal oranlar analizi (Ершова, 2006; Abdyzhaparov, 2013) uygulanmıștır. Bilgimiz dahilinde, Kırgızistan bankalarının etkinliğini SSY ile analiz eden ve fark।ı değișkenlerin bankaların etkinliği üzerindeki etkisini ele alan çalıșmalar yazında mevcut değildir. Dolayısıyla, diğer ülke bankalarından ayrı olarak Kırgızistan bankalarının etkinliğinin SSY'nın uygulanarak farklı sonuçlar elde edilebilmesi açısından bu çalıșma literatüre katkı sağlamaktadır.

Kırgızistan'ın bankacılık sektörünün etkinliğini araștıran mevcut çalıșmalardan (Keleș, 2011; Abdyzhaparov, 2013; Cheng vd., 2013) farklı olarak stokastik sınır yaklașımının uygulanması bu çalıșmamızın geçiș ekonomilerinde bankacılık kurumlarının etkinliği ile ilgili literatüre katkı sağlamaktadır. Bununla birlikte, kullanılan veri seti son dönemlerdeki gelișmeleri ve daha fazla sayıdaki bankaları da kapsamaktadır.

Bilgimiz dahilinde, Kırgızistan bankalarının kar etkinliğinin ölçülmesinde SSY kullanılan yazındaki tek çalıșma Djalilov ve Piesse (2014)'in çalıșmasıdır. Dialilov ve Piesse (2014) SSY uygulayarak 2000-2011 dönemi için Orta Asya ve Baltik ülkelerindeki bankalarının kar etkinliğini araștırmıșlardır. Bu çalıșmada Kırgızistan'da mevcut olan 18-25 bankanın sadece 3 bankası incelenmiștir. Çalıșmada bankaların kar etkinlikle- 
ri faaliyet gösterdiklerin ülkelere göre gruplandırılarak karșılaștırılmıștır. Ayrıca, Kırgızistan'daki bankaların kar etkinlikleri ortalama olarak 0,63 düzeyinde hesaplanmıștır.

Ancak, bazı yazarlar farklı ülkelerde faaliyet gösteren bankaların verileri kullanılarak ortak etkinlik sınırına göre hesaplanan etkinlik skorlarının sapmalı hesaplanmasına yol açabileceğini belirtmektedirler (Chaffai vd., 2001; Bos ve Schmiedel, 2007; Lozano-Vivas ve Pastor, 2010). Diğer ülke bankalarından ayrı olarak, Kırgızistan bankalarının etkinliğini SSY ile analiz eden ve seçilmiș değișkenlerin bankaların etkinliği üzerindeki etkisi ile ilgili çalıșmalar, bilgimiz dahilinde mevcut değildir.

Yazındaki çalıșmaların incelenmesi sonucunda bu çalıșmanın yazındaki mevcut çalıșmalardan esas farklılıkları dört yönden ele alınabilir. Diğer ülke bankalarından ayrı olarak Kırgızistan bankalarının etkinliğinin SSY ile ölçülmesidir. Ikinci olarak, hem zaman hem de banka sayısı açısından daha geniș veri setinin kullanılmasıdır. Üçüncü olarak, maliyet etkinliğinin analiz edilmesidir. Dördüncü olarak da, seçilmiș değișkenlerin bankaların etkinliği üzerindeki etkisinin incelenmesi. Bu araștırmanın literatüre olan katkısı esas olarak bu farklılıklardan olușmaktadır.

\section{Yöntem ve Model}

\subsection{Yöntem}

Bu çalıșmada bankaların maliyet etkinliğinin ölçülmesinde parametrik ve ekonometrik yaklașım olarak bilinen ve ilk olarak Meeusen ve van den Broeck (1977)'un, ve Aigner vd. (1977)'in çalıșmalarında önerilmiș olan Stokastik Sınır Yaklașımı uygulanmıștır. Bu çalıșmalarda, tesadüfi yapı hesaba alınmadan etkinlik sınırının hesaplanması yanıltıcı olabileceği belirtilerek SSY önerilmektedir. Aigner vd., (1977) tarafından tanımlanan SSY'nın temel modeli așağıdaki gibidir:

$$
\begin{aligned}
y_{i}=f\left(x_{i}, \beta\right)+\varepsilon_{i}, & \underline{i}=1,2,3, \ldots, l \\
\varepsilon_{i}=v_{i}-u_{i}, & u_{i} \geq \underline{\underline{0,}} i=1,2,3, \ldots, l \\
y_{i}=f\left(x_{i}, \beta\right)+v_{i}-u_{i}, &
\end{aligned}
$$

Burada $y_{i}$, i. firmanın üretilen çıktı miktarını; $x_{i}$, i. firmanın $(1 \times K)^{\prime}$ lık girdi vektörünü; tahmin edilmesi gereken ve bilinmeyen parametreler vektörünü; $\varepsilon_{i}, N\left(0, \sigma_{\varepsilon}^{2}\right)$ dağılan kompozit (birleșik) hata te- 
rimini; $v_{i}$ bağımsız ve simetrik $N\left(0, \sigma_{v}^{2}\right)$ dağılım gösteren ve verilerdeki gürültüyü ve genellikle beyaz gürültü sseklinde belirtilen rassal hata terimini (Kumar ve Gulati, 2014:98) ve/veya spesifikasyon hatalarını (Belotti vd., 2013:722), banka yönetiminin kontrolü dıșında belirlenen, beklenmeyen, verilerdeki veya ölçüm hatasından kaynaklanan rassal faktörlerin etkisi sonucunda meydana gelen bankanın çıktısındaki artıș veya düșüșleri (Isik ve Hassan, 2002:262); $u_{i}$ ise negatif değer almayan ve sıfırda kesilmiș $N\left(0, \sigma_{u}^{2}\right)$ dağılımından türetilen ve asimetrik tek taraflı yarı normal dağılım gösteren (Kasman, 2003:86) etkinsizliği temsil eder. Hata terimi ve etkinsizlik ölçüleri birbirinden bağımsız dağılıma sahip rassal değișkenlerdir. Kavramların karıștırılmasından kaçınmak amacıyla, $v_{i}^{\prime}$ nin iki taraflı hata terimi veya istatistiki gürültü; $u_{i}$ etkinsizlik terimi veya etkinsizlik bileșeni; $\varepsilon_{i}$ kompozit (birleșik) hata terimi olarak belirtilmiștir.

Modelde etkinsizlik bileșeni $u_{i}{ }^{\prime}$ nin olması birimlerin üretim miktarlarının üretim sınırı üzerinde veya alında olmasına neden olur (Parmeter ve Kumbhakar, 2014:4). Pozitif olmayan etkinsizlik ölçüsü, her bir firmanın çıkısının $\left[f\left(x_{i}, \beta\right)+v_{i}\right]$ șeklinde ifade edilebilecek sınırda veya sınırın alıındaki miktarda olacağını ifade etmektedir. Firmanın çıktı miktarı ile sınır arasındaki mesafe, teknik ve tahsis etkinsizliği, ișçilerin ve yöneticilerin çaba ve iradesi, arızalı ve hasarlı ürün gibi firmanın kontrolü altındaki faktörlerin sonucudur (Aigner vd., 1977:25).

Üretim fonksiyonunda bağımlı değișken olan çıktı miktarı, girdilerin bir fonksiyonudur. Benzer șekilde, maliyet fonksiyonunda ise, maliyetler girdi fiyatları ve çıkı miktarlarının bir fonksiyonu șeklinde ifade edilir. Girdi fiyatları ve çıktı miktarları veri iken üretim sürecinde optimum girdi bileșiminin kullanılmasıyla mümkün olan minimum maliyet düzeyi yardımıyla maliyet fonksiyonu tanımlanabilir. Denklem (1-2)'deki fonksiyonun genișletilmesiyle stokastik maliyet fonksiyonu matematiksel olarak bu șekilde yazılabilir:

$$
\begin{array}{cl}
T C_{i t} \geq c(y, w, \beta) \times \exp \left\{v_{i t}\right\}, & \underline{\underline{i}}=1,2,3, \ldots, I ; t=1,2,3, \ldots, T \\
T C_{i t}=c(y, w, \beta) \times \exp \left\{v_{i t}+u_{i t}\right\}, & u_{i} \geq 0, i=1,2,3, \ldots, \underline{\underline{I}} t=1,2,3, \ldots, T
\end{array}
$$

Türevinin alınabilmesi için değişkenlerin logaritması alındıktan sonra:

$$
\begin{array}{rc}
\ln T C_{i t}=\ln c(y, w, \beta)+v_{i t}+u_{i t}, & u_{i} \geq 0, i=1,2,3, \ldots, \underline{\underline{\underline{I i}}} t=1,2,3, \ldots, T \\
T C_{i t}=\exp \{\ln c(y, w, \beta)\} \cdot \exp \left\{u_{i t}\right\} \cdot \exp \left\{v_{i t}\right\}, & u_{i} \geq 0, i=1,2,3, \ldots, \underline{\underline{\underline{I i}}} t=1,2,3, \ldots, T \\
C E_{i t}=\left[c(y, w, \beta) \times \exp \left\{v_{i t}\right\}\right] / T C_{i t}=\exp \left\{-u_{i t}\right\}, & u_{i t} \geq 0 ; 0<C E_{i t} \leq 1
\end{array}
$$


$T C_{i t}$, üretim sürecinde gerçekleștirilen toplam maliyetleri; $y$ ile çıkıların miktarının, $w$ ile girdilerin fiyatlarının vektörü; $\left[c(y, w, \beta) \operatorname{xexp}\left\{v_{i t}\right\}\right]$ ile stokastik maliyet sınırı ifade edilmiștir.

Burada $C E_{i t}$ ile ifade edilen maliyet etkinliği, olușturulan maliyet fonskiyonunun gerçek veriler kullanılarak tahmin edilen parametrelerine göre belirlenen maliyetlerin teorik sınırından sapmalara göre hesaplanmaktadır. $C E_{i t}$ teorik sınırda değer alan minimum maliyetin gözlemlenen maliyete bölünmesiyle hesaplanır (Staikouras vd., 2008:488). Diğer bir ifade ile, fiyatları veri olan girdilerin etkin kullanılması için optimum bileșenin kullanılmasıyla veri olan çıktı miktarının üretimi için gözlemlenen toplam maliyetin $\left(T C_{i t}\right)$ ne kadarlık kısmı yeterli olduğunu ifade etmektedir. Gözlemlenen bankanın maliyeti tahmin edilen maliyet sınırına yakınlık derecesine göre hesaplandığından dolayı sınır değerine en yakın maliyete sahip banka en iyi performansa sahip banka olarak değerlendirilir.

\subsection{Model}

Panel verilere uygulanabilecek birçok alternatif modellerin olmasına rağmen, yazındaki çalıșmaların çoğunda Battese ve Coelli (1995)'nin "etkinlik etkileri" modeli ve son yıllarda yaygınlașan Greene $(2005 a, b)$ 'in "gerçek" sabit etkiler ve "gerçek" rassal etkiler modelleri uygulanmıștır (Duygun vd., 2014; Spulbăr vd., 2015). Battese ve Coelli (1995)'nin modelinde firma etkileri (heterojenlik) etkinsizlik ile karıșımı ele alınmaktadır. Simetrik rassal hata, etkinlik ve firma etkisi olmak üzere üç bileșene ayrılmasına imkan sağlayan Greene (2005a,b)'in "gerçek" sabit etkiler ve "gerçek" sabit etkiler modellerinde zamanla değișmeyen heterojenliğin tümü zamanla değișmeyen etkiler olarak varsayılmaktadır. Bunun sonucunda, etkinlik ölçüleri olduğundan daha yüksek $(1$ 'e yakın) ve bankalar arasında da biribirine çok yakın (neredeyse eșit) düzeylerde hesaplanmaktadır. Bu soruna karșı çözüm olarak Shen vd. (2009)'da bankalara özgü değișkenlerin etkisi vasıtasıyla bankalar arasındaki heterojenlik hesaba alınabilen Battese ve Coelli (1995)'nin modeli önerilmiștir.

Ne girdi değișkeni, ne de çıkłı değișkeni olan fakat etkinlik ölçülerinin dağılımını etkilediği farzedilen dıșsal değișkenlerin modele dahil edilmesi SSY'nın önemli bir konusu haline gelmiștir. Çünkü, dıșsal faktörlerin etkisi, sınır fonksiyonunun ve etkinlik ölçülerinin dağılımının kaymasına ve/veya ölçeklendirilmesine neden olabilmekte (Belotti vd., 2013:726). Bu sorunlara karșı çözüm olarak dıșsal değișkenleri hesaba 
alan SSY panel veri modelleri geliștirilmiștir. SSY uygulanan yazındaki çalıșmaların çoğunluğunda söz konusu modellerden Battese ve Coelli (1995)'nin etkinsizlik etkileri modeli uygulanmıștır (örn., Kasman ve Carvallo, 2013; Glass vd., 2014). Bu modelin sağladığı avantajlar: dengesiz panel verilere de uygulanabilmesi; dısssal değișkenlerin etkinsizlik ölçüsü üzerindeki etkisinin; ve iki basamaklı (two-step) SSY yaklașımlarından farkı olarak dıșsal değișkenlerin eșanlı olarak tahmin edilebilmesidir.

$$
\begin{aligned}
\ln T C_{i t}=\alpha+ & \sum_{m=1}^{M} \beta_{m} \ln Q_{m i t}+\sum_{n=1}^{N} \gamma_{n} \ln W_{n i t} \\
& +1 / 2\left(\sum_{m=1}^{M} \beta_{m m}\left(\ln Q_{m i t}\right)^{2}+\sum_{n=1}^{N} \gamma_{n n}\left(\ln W_{n i t}\right)^{2}\right) \\
& +\sum_{m=1}^{M} \sum_{r=1}^{R} \sum_{m \neq r}^{M, R} \beta_{m r} \ln Q_{m i t} \ln Q_{r i t}+\sum_{n=1}^{N} \sum_{s=1}^{S} \sum_{n \neq s}^{N, S} \gamma_{n s} \ln W_{n i t} \ln W_{s i t} \\
& +\sum_{m=1}^{M} \sum_{n=1}^{N} \varphi_{m n} \ln Q_{m i t} \ln W_{n i t}+u_{i t}+v_{i t}
\end{aligned}
$$

Bu denklemdeki $\ln T C_{i,}, \ln Q_{m i,}, \ln W_{n i t}, i$. bankanın $t$. dönemindeki (sırasıyla) toplam maliyetini (faiz, faiz dıșı ve operasyonel maliyetlerin toplamı), m. çıkııının miktarı, n. girdisinin fiyatınının doğal logaritmalarını; $\alpha, \beta, \gamma, \varphi$, ise tahmin edilecek parametreleri; $u_{i t}$ ve $v_{i t}$ sırasıyla etkinsizlik terimini ve beyaz (istatistiki) gürültüyü ifade etmektedir. Bu modeldeki etkinsizlik ve hata terimlerinin dağılımları bu șekildedir:

$$
\begin{gathered}
u_{i t} \sim N^{+}\left(\mu_{i t}, \sigma_{u}^{2}\right) \\
v_{i t} \sim N\left(0, \sigma_{v}^{2}\right)
\end{gathered}
$$

Dıșsal değișkenlerin etkinsizlik üzerindeki etkileri etkinsizlik teriminin ortalaması $\left(u_{i t}\right)$ dıșsal değișkenlerin doğrusal fonksiyonu șeklinde ifade edilen, ve tek așamalı prosedür ile (eș anlı olarak) tahmin edilen yardımcı denklem bu șekilde yazılabilir:

$$
\mu_{i t}=\xi_{0}+\sum_{k=1}^{K} \xi_{k} z_{k i t}
$$

Burada, $z_{i t}$ ile etkinsizlik terimini etkileyen bankaya özgü ve dıșsal değișkenleri; $\xi$ ile tahmin edilecek katsayıların vektörü gösterilmiștir. Bu denkleme beyaz (istatistiki) gürültü niteliğindeki hata teriminin, yani $\omega_{i i}{ }^{\prime}$ nin eklenmesi ve bankaya, sektöre ve ekonomiye özgü değișkenlerin tek tek gösterilmesiyle denklem (12)'nin açık șekli denklem (13)'teki 
șekilde yazılabilir. Bu denklemdeki parametreler denklem (9) ile eș anlı olarak tahmin edilecektir. Stokastik sınır modellerinde esas ve yardımcı denklemlerin eș anlı olarak tahminini öngören (tek așamalı) prosedürün iki așamalı tahminini öngören prosedüre göre üstünlükleri literatürdeki çalıșmalarda açıklanmıștır (Battese ve Coelli, 1995; Wang \& Schmidt, 2002; Schmidt, 2011).

$$
\begin{gathered}
u_{i t}=\xi_{0}+\xi_{1} C A R_{i t}+\xi_{2} L I Q R_{i t}+\xi_{3} \text { FOREIGN }_{i t}+\xi_{4} S \text { SREAD }_{t} \\
+\xi_{5} \text { GDP }_{-} G R W_{t}+\xi_{6} S T D E V_{-} F X_{t}+\xi_{7} L N T A_{i t}+\xi_{8} S L L R_{i t}+\omega_{i t} \\
\omega_{i t} \sim N^{+}\left(-z_{i t}^{\prime} \xi, \sigma_{\omega}^{2}\right)
\end{gathered}
$$

Belirtilen denklemlerde, $u_{i t}$ bağımsız, ancak özdeșçe simetrik olmayan dağılan etkinsizlik terimi; $v_{i t}$ ve $\omega_{i t}$ beyaz (istatistiki) gürültü veya rassal hata; $\sigma_{u}^{2}$ ve $\sigma_{v}^{2}$ ile sırasıyla 'nin varyansları ifade edilmiștir.

\section{Değișkenler ve Veri Seti}

Çoğu çalıșmalarda bankaların girdi ve çıkłı değișkenlerinin belirlenmesinde neoklasik firma teorisi çerçevesinde Sealey ve Lindley (1977) tarafından önerilen ve temel rolünün finansal aracılık olduğunu öne çıkaran finansal aracılık yaklașımı izlenmiștir. Bu yaklașıma göre bankaların emek ve fiziki sermaye kullanarak mobilize ettiği mevduatları ve borçlanarak ulaștığı diğer fonları gelir getiren varlıklara dönüștürdüğü; ve veri olan girdi fiyatları dikkate alınarak veri olan çıkı düzeyinin üretimi için çıkıların girdi miktarlarının optimum bileșimlerini kullanmaya çaba gösterdikleri varsayılmaktadır (Berger ve De Young, 1995; Altunbas vd., 2000; Casu ve Girardone, 2005; Chen vd., 2015).

Fakat bu yaklașımda bankaların hesap açma, banka kartları çıkarma, havale ișlemleri gibi hizmetler sunduğu ihmal edilmesinden dolayı (Kumar ve Gulati, 2014:246), yazındaki bazı çalıșmalar (Altunbas vd., 2000; Nigmonov, 2010; Mamonov, 2013; Dong vd., 2015) izlenerek Kırgızistan bankalarının girdi ve çıktıları emek ve fiziki sermayenin faiz dıșı gelir getiren faaliyetlerin gerçekleștirilmesi için de kullanıldığını esas alan varlıklar yaklașımının modifiye (Tente, 2010:67) veya Matthews vd. (2009)'de belirtildiği gibi, genișletilmiș (hibrid) varlıklar yaklașımına göre belirlenmiștir. Bu yaklașıma göre üçüncü bir çıkłı olarak bankaların bilanço dıșı ișlemlerinden elde edilen gelirleri de kapsayan faiz dıșı gelirleri belirlenmiștir. 


\subsection{Girdiler ve çוktılar}

Bankaların girdileri olarak emek, sermaye, mevduatlar ve satın alınan diğer fonlar șeklinde belirlenmiștir. Maliyet fonksiyonunda girdi miktarlarından ziyade girdi fiyatları kullanılmaktadır. Emeğin fiyatı $\left(W_{l}\right)$ toplam personel giderlerinin toplam varlıklara oranı, fiziki sermayenin fiyatı $\left(W_{2}\right)$ operasyonel giderlerden personel giderlerinin çıkartılmasından sonraki giderlerin duran varlıkların bilanço değerine oranı, üçüncü bir girdinin fiyatı $\left(\mathrm{W}_{3}\right)$ toplam faiz giderlerinin finansal fonlara oranı șeklinde ölçülerek kullanılmıștır.

Yazındaki bazı çalıșmalar (Casu ve Girardone, 2005:1056; Koetter, 2006; Košak vd., 2009; Nigmonov, 2010:10) izlenerek çıkılar olarak bankanın müșterilere ve diğer finansal kurumlara sağlanan kredilerden mühtemel kayıp ve zararlar için ayrılan rezervlerin çıkartılması sonucundaki elde edilen net krediler $\left(Q_{1}\right)$, bankaların bilançosunda kaydedilmiș menkul kıymetler ve yatırımlar $\left(Q_{2}\right)$, bankaclık faaliyetinin diğer kollarını da kapsayan diğer bir çıkłı türü olarak faiz dıșı gelirler $\left(Q_{3}\right)$ belirlenebilmiștir.

\subsection{Bankaya özgü ve dișsal değișkenler}

Aynı ülkedeki bankalar etkinliğinin tek etkinlik sınııına göre ölçülmesi durumunda banka özelliklerini kapsayan kontrol değișkenlerin modele yerleștirilmesiyle bankalar arası heterojenlik sorununun azaltılması mümkün olabilmektedir. Bankaların maliyetleri ve karları, dolayısıyla iktisadi etkinliklerini etkilediği varsayılan değișkenleri bankalarca kontrol edilebilir (bankaya özgü) ve kontrol edilemeyen (dıșsal) değișkenler olarak ayırmak mümkündür.

Yazındaki bazı çalıșmalar izlenerek bankaların büyüklük, sahiplik ve risk alma eğilimlerine göre heterojenliklerinin hesaba alınması ve bankaların maliyet etkinliği üzerindeki etkisini incelemek üzere modele dahil edilmiștir (Kasman ve Carvallo, 2013; Goddard vd., 2014). Banka büyüklüğünün temsili değișkeni olarak toplam varlıkların doğal logaritması (LNTA) (Altunbas vd., 2007; Sufian ve Habibullah, 2012:25; Ferhi ve Chkoundali, 2015); banka sahiplik yapısının kontrolü için bankanın özsermayesinin \% 50 'si ve üzeri yabancı sermayeden olușan banka yabancı banka (1) olarak belirlenen kukla değișkeni (FOREIGN); bankalar arasında risk alma eğilimindeki farklılıkların kontrolü için özsermayenin varlıklara oranı (CAR) (Altunbaș vd., 2001a; Williams, 2004; Duygun vd., 2014:509); likidite riski değișkeni likit varlıkların toplam varlıklara oranı (LIQR) (Kasman ve Carvallo, 2013). kredi riskinin temsili değișkeni 
sorunlu krediler ile ilgili mühtemel kayıp ve zararların karșılanması için olușturulan rezervlerin net kredilere oranı (SLLR) (Altunbas vd., 2007; Kenjegalieva vd., 2009:1535; Huang vd., 2014).

Makroekonomik ve bankacılık sektörel faktörlerin bankaların maliyet etkinliğini etkilediği varsayılarak ve yazındaki bazı çalıșmalar izlenerek etkinlik ölçülerindeki sapmaların azaltılması için (Jarraya, 2014) GSYiH'nın yıllık büyüme oranı (GDP_GRW) (Mamonov, 2013; Kasman ve Carvallo, 2013; Goddard vd., 2014:141); bağlantılı ülkelerdeki gelișmelerin etkisini, döviz piyasası durumunu ve döviz kuru riskini belirli bir ölçüde yatsıtığı varsayılarak ve ABD dolarının değișim kurunun standart sapması (STDEV_FX) (Mamonov, 2013); rekabetteki değișimleri yansıttığı varsayımı temel alınarak bankaların uyguladıkları kredi ve mevduat faiz oranları arasındaki farkı (SPREAD) (Drakos, 2003; Quagliariello, 2007; Huang vd., 2014) tahmin edilen modele kontrol edilemeyen (dıșsal) değișkenler olarak dahil edilmiștir.

\subsection{Veri seti}

Bu çalıșmada 2000-2013 döneminde faaliyette bulunan 23 ticari bankaya ait yıllık ve dengesiz panel veri seti kullanılmıștır. Fakat, bankacılık sisteminde istikrarın korunması amacıyla bazı bankaların bazı yıllardaki faaliyetleri merkez bankası tarafından kısıtlanmıștır. Bu kısıtlamalardan dolayı bazı bankalar rakiplerine kıyasla aynı șartlarda faaliyet gösterememișlerdir. Bundan dolayı bazı bankaların bazı yıllardaki verileri kullanılmamıștır. Tablo 1.'de Kırgızistan'daki tüm bankaların ve veri setine dahil edilen bankaların sayısının 2000-2013 dönemi içindeki değișimi gösterilmiștir. Tablo'dan 2002-2006 ve 2008 'de bankacılık sektöründeki tüm bankaların verileri kullanıldığı görülmektedir. 2000-2001 ve 2010-2013 dönemlerindeki gözlemlenen banka sayısındaki azalmalar bankacılık sisteminde bu dönemlerde yașanan istikrarsızlıklar ile ilgilidir. 1998'de Rusya Krizinin ve 2010'daki siyasi istikrarsızlıkların olumsuz etkisinin sonucunda bazı bankalar sıkı gözetim ve sınırlandırmalara tabi kalmıșlardır.

Tablo 1: Kırgızistan Bankacılık Sektöründe 2000-2013 döneminde Mevcut olan ve Veri Setine Dahil Edilen Bankaların Sayısı

\begin{tabular}{|c|c|c|c|c|c|c|c|c|c|c|c|c|c|c|}
\hline YIllar & ষ্ণ & ষ্ন & ర్ & ర్లి & ర্ন & ஜ̊ & ষ্ণ & ઠิ & ஜ̊ & ઠ & 음 & $\bar{\delta}$ & $\frac{\text { N }}{\text { ก }}$ & $\frac{m}{\text { D }}$ \\
\hline & 23 & 22 & 19 & 19 & 18 & 19 & 20 & 22 & 21 & 22 & 22 & 22 & 23 & 24 \\
\hline $\begin{array}{l}\text { Veri setine dahil } \\
\text { edilen }\end{array}$ & 16 & 19 & 19 & 19 & 18 & 19 & 20 & 20 & 21 & 21 & 17 & 18 & 19 & 20 \\
\hline
\end{tabular}

Kaynak: 2000-2013 yılları için Kırgız Cumhuriyeti Merkez Bankası Yıllık Raporları 
Veriler ticari bankalarca gazetelerde ve resmi internet sitesilerinde yayınlanmıș bilanço ve gelir tablosundan temin edilmiștir. Makroiktisadi ve bankacılık sektörü değișkenleri ile ilgili verilerin temin edilmesinde Kırgız Cumhuriyeti Merkez Bankası ve Dünya Bankası veri tabanlarından yararlanılmıștır. Kullanılan veri setine ait bilgi ve betimsel istatistikler Tablo 2.'de sunulmuștur. Bin Som olarak gösterilmiș olan toplam maliyetlerin ve çıkı miktalarının GSYiH deflatörüne gore reelleștirilmiș değerleri kullanılmıștır.

Tablo 2: Kırgızistan Ekonomisi, Bankacılık Sektörü ve Ticari Bankalara Ait Betimleyici İstatistikler

\begin{tabular}{|c|c|c|c|c|c|}
\hline $\begin{array}{l}\text { Değișken } \\
\text { notasyonu }\end{array}$ & Açıklama & Ortalama & $\begin{array}{l}\text { Standart } \\
\text { sapması }\end{array}$ & Min. & Maks. \\
\hline TC & $\begin{array}{l}\text { Toplam maliyetler }=\text { toplam faiz gi- } \\
\text { derleri }+ \text { toplam faiz diș giderler }+ \\
\text { toplam operasyonel giderler, (bin } \\
\text { Som)* }\end{array}$ & 202592 & 438802 & 6105 & 4314728 \\
\hline$Q_{1}$ & $\begin{array}{l}\text { Toplan net krediler }=\text { müșterilere ve } \\
\text { diğer finansal kurumlara sağlanan } \\
\text { krediler - sorunlu krediler ile ilgili } \\
\text { mühtemel kayıp ve zararların kar- } \\
\text { șılanması için olușturulan rezervler, } \\
\text { (bin Som)* }\end{array}$ & 459825 & 562301 & 520 & 3343711 \\
\hline$Q_{2}$ & Menkul kıymetler, (bin Som)* & 133911 & 241526 & 0.3 & 1921961 \\
\hline$Q_{3}$ & Faiz dıșı gelirler (bin Som)* & 46568 & 72651 & 150.9 & 714200 \\
\hline$W_{1}$ & $\begin{array}{l}\text { Emeğin fiyatı = toplam personel gi- } \\
\text { derleri/toplam varlıklar* }\end{array}$ & 0.0422 & 0.0220 & 0.0006 & 0.1269 \\
\hline$W_{2}$ & $\begin{array}{l}\text { Fiziki sermayenin fiyatı = (operasyo- } \\
\text { nel giderler - toplam personel giderle- } \\
\text { ri)/duran varlıklar* }\end{array}$ & 1.0992 & 1.8931 & 0.108 & 24.6168 \\
\hline$W_{3}$ & $\begin{array}{l}\text { Satın alınan fonların fiyatı = toplam } \\
\text { faiz giderleri/toplam fonlar (vadeli } \\
\text { mevduatlar + borçlanma)* }\end{array}$ & 0.0479 & 0.0380 & 0.001 & 0.2539 \\
\hline CAR & $\begin{array}{l}\text { Ödenmiș özsermaye / toplam varlık- } \\
\text { lar* }\end{array}$ & 0.2739 & 0.1405 & 0.071 & 0.9246 \\
\hline$L I Q R$ & Likit varlıklar/toplam varlıklar* & 0.2954 & 0.1613 & 0.0008 & 0.8493 \\
\hline FOREIGN & $\begin{array}{l}\text { Sahiplik yapısı kukla değișkeni. } \\
\text { Ödenmiș sermayesinin \% } 50 \text { 'si ve } \\
\text { üzeri payı yabancı kișilere ait ise 1, } \\
\text { diğerleri için sıfır olarak olușturulan } \\
\text { kukla değișken* }\end{array}$ & 0.4179 & 0.4941 & 0.000 & 1.0000 \\
\hline SPREAD & $\begin{array}{l}\text { Faiz oranı = kredi faiz oran - mevdu- } \\
\text { at oranı, } \% * *\end{array}$ & 24.0 & 5.4102 & 17.1 & 41.3 \\
\hline GDP_GRW & $\begin{array}{l}2005 \text { sabit fiyatlar ile GSYiH'nın yıllık } \\
\text { büyüme oranı, \% ** }\end{array}$ & 4.6310 & 3.6165 & -0.5 & 10.9 \\
\hline
\end{tabular}




\begin{tabular}{|c|l|c|c|c|c|}
\hline STDEV_FX & $\begin{array}{l}\text { ABD dolarının değișim kur oranı var- } \\
\text { yansı, 2000-2009-yılları için haftalık } \\
\text { veriler, 2010-2013 yıllar için günlük } \\
\text { veriler ile hesaplanmıștı*** }\end{array}$ & 0.9444 & 0.4150 & 0.2000 & 1.7000 \\
\hline LNTA & $\begin{array}{l}\text { Banka büyüklüğü=Toplam varlıkların } \\
\text { doğal logaritması* }\end{array}$ & 13.8014 & 1.3335 & 10.446 & 16.9127 \\
\hline SLLR & $\begin{array}{l}\text { Sorunlu krediler ile ilgili mühtemel } \\
\text { kayıp ve zararların karșılanması için } \\
\text { olușturulan rezervler /net krediler* }\end{array}$ & 0.0596 & 0.1458 & 0.000 & 1.5193 \\
\hline
\end{tabular}

Not: Min.: minimum değeri; Maks.: maksimum değeri

Kaynak: Resmi gazeteler ve bankaların resmi sitesinde yayınlanan finansal raporlar (*), Dünya Bankası (**), Kırgız Cumhuriyeti Merkez Bankası (***).

\section{Analiz Sonuçları}

Maksimum olabilirlik tahmincilerinin alternatif tahmincilere göre asimptotik olarak daha etkin olması (Košak vd., 2009), bankaya özgü etkinlik ölçülerinin elde edilebilmesine imkan sağlaması (Hassan, 2008:362) ve dağılımlar ile ilgili bilgilerin kullanılabilmesi SSY modelleri tahmin edilen çalıșamlarda daha çok maksimum olabilirlik yönteminin tercih edilmesine neden olmuștur (Lampe ve Hilgers, 2015:2). Bu yönteme göre, gözlemlenen değerlerin gerçekleșme olasılığını mümkün olduğunca yüksek yapan etkinlik sınırı fonksiyonunun parametrelerin vektörü seçilmektedir (Bogetoft ve Otto, 2011:198). Bu çalıșmada uygulanan Battese ve Coelli (1995)'nin modelinin tahmin edilmesinde maksimum olabilirlik yöntemi uygulanmıștır.

Dualite teoremi, maliyet fonksiyonunda yer alan girdi fiyatlarnın doğrusal homojenliğini ve ikinci dereceden parametrelerin simetrik olmasını gerektiğinden dolayı, fonksiyon parametrelerine bu șekildeki șartların sağlanmasını gerektirmektedir: $\sum_{n=1}^{N} \gamma_{n}=1, \sum_{n=1}^{N} \sum_{s=1}^{S} \gamma_{n s}=0$ $\sum_{m=1}^{M} \sum_{n=1}^{N} \varphi_{m n}=0$. Maliyet fonsiyonunda girdi fiyatlarındaki doğrusal homojenlik șartı $T C_{i t}, W_{l i t}$ ve $W_{2 i t}{ }^{\prime}$ nin $W_{3 i t}{ }^{\prime} \mathrm{e}$ bölünmesi șeklinde dönüșüm ile sağlanmıștır. İlgili parametrelerde $\gamma_{n s}=\gamma_{s n}, \beta_{m r}=\beta_{r m}$ șeklindeki kısııı sağlanması ile simetrik șartı yerine getirilmișțir.

Tahmin edilen modele ait parametre sonuçları Tablo 3.'te sunulmuștur. Tablonun ilk kısmında maliyet sınır fonksiyonunda yer alan değișkenler ile ilgili tahmin sonuçlarını betimleyen istatistiki bilgiler sunulmuștur.

Tahmin sonuçlarına göre, $\beta_{2}$ hariç girdi fiyatları ve çıkı miktarlarına ait katsayıların tümü pozitif ișaretli ve \%1 düzeyinde istatistiksel olarak anlamlıdır. Tahmin edilen katsayıların ișaretinin pozitif olması ik- 
tisadi teoriye ve beklentilerimize uyumluluk sağlamaktadır. Girdi fiyatları ve çıtıların ikinci dereceden katsayıları ve çapraz çarpımlarına ait katsayıların çoğu en az \% 10 düzeyinde istatistiki olarak sıfırdan farklıdır.

Tahmin edilen katsayıların büyüklüğüne göre, bankaların maliyetlerini arttırma yönünde en büyük ölçüde etkileyen değișkenler faiz dıșı gelirlerin hacmi $\left(\ln Q_{3}\right)$, ișgücü fiyatı $\left(\ln W_{1}\right)$ ve fon kaynaklarının fiyatıdır $\left(\ln W_{2}\right)$.

Tablo 3: Maliyet SSY Stokastik Maliyet Etkinlik Sınırı Tahmin Sonuçları

\begin{tabular}{|c|c|c|c|c|c|c|c|}
\hline Değișken & Parametre & değeri & t-değeri & Değișken & Parametre & değeri & t-değeri \\
\hline \multicolumn{8}{|c|}{ Maliyet Sınırı Denklemi } \\
\hline $\ln Q_{1}$ & & $0.398^{* * *}$ & (3.64) & $\ln Q_{1} \ln W_{2}$ & & $0.0777^{* * *}$ & $(4.13)$ \\
\hline $\ln Q_{2}$ & & $0.0800 * *$ & $(2.06)$ & $\ln Q_{2} \ln W_{1}$ & & 0.0000729 & $(0.01)$ \\
\hline $\ln Q_{3}$ & & $0.731^{* * *}$ & (12.14) & $\ln Q_{2} \ln W_{2}$ & & 0.0133 & $(1.19)$ \\
\hline $\ln W_{1}$ & & $0.659 * * *$ & $(6.52)$ & $\ln Q_{3} \ln W_{1}$ & & -0.0164 & $(-0.85)$ \\
\hline $\ln W_{2}$ & & $0.593^{* * *}$ & $(7.69)$ & $\ln Q_{3} \ln W_{2}$ & & $-0.0237^{*}$ & $(-1.71)$ \\
\hline $\ln Q_{1} \ln Q_{1} / 2$ & & $0.0419^{*}$ & $(1.87)$ & $\ln W_{2} \ln W_{1}$ & & $-0.112^{* * *}$ & $(-5.14)$ \\
\hline $\ln Q_{2} \ln Q_{2} / 2$ & & $0.0128^{* * *}$ & $(5.54)$ & $\ln Q_{1} \ln Q_{2}$ & & $-0.041^{* * *}$ & $(-5.27)$ \\
\hline $\ln Q_{3} \ln Q_{3} / 2$ & & $0.151^{* * *}$ & $(12.75)$ & $\ln Q_{1} \ln Q_{3}$ & & -0.00102 & $(-0.06)$ \\
\hline $\ln W_{1} \ln W_{1} / 2$ & & $0.173^{* * *}$ & $(6.28)$ & $\ln Q_{2} \ln Q_{3}$ & & -0.00499 & $(-0.98)$ \\
\hline $\ln W_{2} \ln W_{2} / 2$ & & $0.164^{* \star *}$ & $(7.21)$ & \begin{tabular}{|l|} 
Sabit \\
\end{tabular} & & $3.119 * * *$ & (13.96) \\
\hline $\ln Q_{1} \ln W_{1}$ & & -0.0271 & $(-1.57)$ & & & & \\
\hline \multicolumn{8}{|c|}{ Etkinsizlik Etkileri Denklemi } \\
\hline CAR & & $-3.043^{* * *}$ & $(-2.99)$ & STDEV_FX & & $0.669 * *$ & $(2.46)$ \\
\hline$L I Q R$ & & $0.798^{*}$ & $(1.81)$ & LNTA & & $-0.140^{*}$ & $(-1.68)$ \\
\hline FOREIGN & & $1.494^{* * *}$ & (3.71) & SLLR & & $0.863 * *$ & $(2.21)$ \\
\hline SPREADWB & & $0.0599 * * *$ & $(3.10)$ & Sabit & & -0.514 & $(-0.33)$ \\
\hline GDP_GRW & & $-0.0836^{* *}$ & $(-2.54)$ & & & & \\
\hline$u_{i t}{ }^{\prime}$ in varyansı & & \multicolumn{2}{|l|}{$0.500 * * *$} & \multicolumn{2}{|c|}{ Log-olabilirlik değeri } & \multicolumn{2}{|c|}{11.05} \\
\hline$v_{i t}{ }^{\prime}$ nin varyansı & & \multicolumn{2}{|l|}{$0.117^{* * *}$} & \multicolumn{2}{|c|}{ AIC } & \multicolumn{2}{|c|}{41.90} \\
\hline lambda & & \multicolumn{2}{|l|}{$4.274^{* * *}$} & \multicolumn{2}{|l|}{$\mathrm{BIC}$} & \multicolumn{2}{|c|}{156.6} \\
\hline Gözlem sayısı & & \multicolumn{2}{|l|}{266} & \multicolumn{2}{|c|}{ Ki kare değeri } & \multicolumn{2}{|c|}{5667.0} \\
\hline
\end{tabular}

Not: (1) Maliyet Sınırı Denkleminde bağımlı değișken: InTC; Ełkinsizlik Ełkileri Denkleminde: etkinsizlik ölçüsünün beklenen değeri; (2) t istatistiki değerleri parantez içinde sunulmuștur; (3) *; ** ve ** tahmin edilen katsayının sırasıyla \% 1; \%5 ve \%10 düzeyinde istatistiki anlamlılığını ifade etmektedir.(4) AIC ve BIC, Akaike ve Bayesçi bilgi kriterleri; (5) etkinsizlik etkileri denklemi sonuçları kısmında bağımlı değișken: etkinsizlik ölçüsünün beklenen değeridir.

Faiz dıșı gelirlerdeki \% 1'lik artıș diğer değișkenler sabit iken ortalama olarak toplam maliyetlerdeki \%0,73'lük artıșa neden olmaktadır. Diğer bir ifade ile, Kırgızistan'daki bankaların faiz dıșı gelirlerin kaynağı olan bankacılık ürünlerinin üretimi kredi ve menkul kıymetler portfoyünü olușturma ve bulundurmaya göre daha çok maliyetlere neden olduğuna dair sonuçlar elde edilmiștir. Son yıllarda Kırgızistan bankacılık sektö- 
ründe uygulanmaya bașlayan POS terminal, ATM, internet bankacılığı, mobil bankacılık gibi bankacılık hizmetlerinin üretimi daha çok uzun dönem yatırımlar gerektirmektedir. Bu değișkenin katsayısı, havale, ödeme ișlemleri, bankamatik kartların ihracı gibi faiz dıșı faaliyetler ișgücü ve fiziki sermaye gerektirdiğinden daha çok maliyetlere neden olmasının sonucu olarak değerlendirilebilir.

İșü̈cü fiyatı ve kredilerin miktarındaki değișim, sırasıyla fon kaynaklarının fiyatı ve menkul kıymet ve diğer yatırımların miktarındaki değișime göre toplam maliyetleri daha çok oranda etkilediğine dair elde edilen sonuçlar, Kazakistan (Glass vd., 2014), Rusya (Styrin, 2004; Mamonov, 2013), ve bazı geçiș ekonomilerinin (Staikouras vd., 2008) bankacılık sektörleri araștırılan çalıșmaların sonuçlar ile tutarlı bulunmuștur.

Sonuçlara göre, bankacılığın temel ve geleneksel çıktısı olan kredilerin hacmindeki değișim faiz dıșı gelirlerdeki değișime göre analiz edilen bankaların maliyetlerini daha az oranda etkilemiștir. Kredi portfoyünün hacminin $\left(\ln Q_{1}\right)$ maliyetler üzerindeki göreceli daha düșük düzeyde olması, bankaların ölçek ekonomisi, uzmanlașma ve diğer avanatajlardan yararlanarak bu çıkłı türünün üretimini daha düșük maliyetler ile gerçekleștirebildiklerinin bir sonucu olabilir.

Maliyetlerdeki artıșı en az ölçüde (0,08-086) pozitif yönde etkileyen bankacılık çıktısı olarak menkul kıymetler portföyü hacmi $\left(\ln Q_{2}\right)$ tahmin edilmiștir. Kırgızistan'da menkul kıymetler piyasasının az gelișmiș olması ve bankaların daha risksiz ve düșük maliyetli devlet tahvilleri ve bonoları üzerinden ișlem yürüttüklerinin sonucu olabilir.

Çıktıların ve girdi fiyatlarının ikinci dereceden (çapraz çarpımları ve kareleri) değișkenlerine ait katsayıların bazıları istatistiki olarak anlamsız bulunmuștur. Tahmin edilen bu katsayıların çoğunluğunun özellikleri Eski Soviyetler ülkeleri bankacılık sektörleri için elde edilen önceki çalıșmalardaki (Pilyavskyy vd., 2012; Pestova ve Mamonov, 2013; Glass vd., 2014) bulgular ile tutarlıdır. Çıktı miktarlarının çapraz çarpımlarının katsayılarının negatif bir değer alması bu çıkı türlerinin birbirini tamamlayıcı ürünler olduğunu, dolayısıyla birleșik șekilde üretimi maliyetleri azaltabileceğini göstermektedir. Örneğin, $\ln Q_{1} \ln Q_{2}$ değișkenine ait tahmin edilen katsayının ișaretine göre kredi portföyü ve menkul kıymetler birbirini tamamlayan çıktı türleridir.

Stokastik sınır modellerinin geçerliliğinin sınanmasında kullanılabilir diğer bir önemli parametre Jondrow vd. (1982) tarafından önerilen 
ve $\lambda=\sigma_{u} / \sigma_{v}$ förmülüne göre hesaplanan lambda $(\lambda)$ değeridir. Tablo 2 .'de raporlanan $\lambda$ değerinin istatistiki olarak anlamlı ve 1 'den büyük elde edilmesi, kompozit hata terimindeki değișimlerin büyük kısmının (0.76) maliyet etkisizliğinden kaynaklandığını, dolayısıyla stokastik sınır modeli tanımlamasının geçerliliği olduğunu desteklemektedir.

Tablo 2.'nin ikinci kısmında ise etkinsizlik teriminin beklenen değeri üzerinde etkilediği varsayımı ile maliyet sınır fonksiyonu ile eș anlı olarak tahmin edilen Etkinsizlik Etkileri denklemine ait sonuçlar sunulmuștur. Raporlanmıș tahmin sonuçlarına göre, modelde belirlenen değișkenlerden CAR, FOREIGN, SLLR, LIQR ve STDEV_FX diğer değișkenlere göre etkinsizliğin beklenen değerini daha büyük oranda etkilemiștir.

$C A R^{\prime}$ a ait katsayının negatif ișareti banka sermayeleșmesindeki artıșların etkinsizlikteki azalmalar ile ilișkili olduğunun, ve "ahlaki tehlike" hipotezinin (Berger ve De Young, 1995) Kırgızistan bankalarında geçerliliğinin bir göstergesi șeklinde yorumlanabilir. Daha yüksek sermayeleștirilmiș bankaların maliyetlerinin banka sahiplerinin sıkı kontrolü altında olması ve banka yönetiminin maliyetlerin ve üretim sürecinin daha etkin yönetmesi ile açıklanabilir. Bu sonuçlar yazındaki bazı çalıșmaların sonuçları ile tutarlıdır (Fiordelisi vd., 2011; Radic vd., 2012). Varlıkların büyük kısmı sahiplerin sermayesi ile finanse edilmiș bankalar daha az riskli varlıklar edinme eğiliminde olduğundan dolayı bu bankaların sorunlu kredilerle ile ilgili maliyetleri göreceli daha az, ve hesaplanan maliyet etkinlik ölçüleri daha yüksek olmaktadır.

Bankalarda yabancı sermayenin etkinsizlik üzerinde negatif etkisinin olduğunu destekleyen bazı çalıșmalardan (Bonin vd., 2005; Fries ve Taci, 2005) farklı olarak FOREIGN'in katsayısı pozitif olduğuna dair sonuçlar elde edilmiștir. Katsayısının istatistiki olarak anlamlı ve pozitif ișaretli olması, yabancı sermayeli bankaların ortalama maliyet etkinliklerinin yerel sermayeli bankalara göreceli olarak daha düșük olduğu ifade edilebilmekte. Kamu bankaları dahil yerel bankalar, kamu bankalar ayrıca, ve yabancı sermayeli bankalar olmak üzere üç gruba ait maliyet etkinlikleri Tablo 4.'te sunulmuștur. Kamu bankalarına ait maliyet etkinliği ölçülerinin göreceli olarak daha yüksek olması kamu bütçesinden sübvansiyonlar șeklindeki ucuz finansal fon kaynaklardan yararlanma imkanına sahip olması ile açıklanabilir. 
Tablo 4: Sahiplik Yapısına Göre Bankaların Maliyet Etkinliği

\begin{tabular}{|l|c|c|c|c|c|}
\hline Sahiplik yapısına göre & N & Ortalama & SS & Min & Max \\
\hline Yerel bankalar & 156 & 0.848 & 0.112 & 0.268 & 0.973 \\
\hline Yabancı bankalar & 110 & 0.649 & 0.214 & 0.134 & 0.949 \\
\hline Kamu bankaları & 28 & 0.875 & 0.094 & 0.614 & 0.963 \\
\hline
\end{tabular}

Not: N: gözlem sayısı; SS: standart sapma; Min ve Max: sırasıyla minimum ve maksimum değerleri

Yerel bankaların daha maliyet etkin olması, biriktirdikleri tecrübe ile Kırgızistan bankacılık piyasasının özelliklerini daha yakından tanımaları, ve kurdukları kișisel, kurumsal ve diğer bağlantılar ile açıklanabilir. Yerel koșullarda ilgili maliyetleri daha bașarılı azaltabilen yerel bankalar bankacılık faaliyetini daha az maliyetle gerçekleștirebildiği durum söz konusu olabilir.

SLLR'in katsayı \%5 düzeyde istatistiki olarak anlamlı ve pozitif ișaretli bulunmuștur. Elde edilen tahmin sonuçları kredi riski yönetiminde bașarısız olan banka yönetiminin maliyetlerin yönetiminde de bașarısız olduğu öne sürülen "kötü yönetim" hipotezinin (Berger ve De Young, 1995) Kırgızistan bankacılık sektöründe geçerliliğini destekleyen bulgu olarak değerlendirilebilir.

$L I Q R^{\prime}$ nin \%10 önem seviyesinde istatistiki olarak anlamlı bulunan katsayısının pozitif ișareti, likiditesi yüksek bankaların daha riskli kredileme faaliyetinden kaçınarak finansal fon kaynaklarını düșük riskli ve likit varlıklara yönlendirmesi sonucunda, bu kaynaklar, ișgücü ve fiziki sermaye ile ilgili sabit maliyetler bankaların maliyet etkinliğinin daha düșük olmasına neden olduğu durumu yansıtabilir.

Kırgızistan ekonomisi ve bankacılık sektörünün küçük ve açık olmasından dolayı dıș ülkelerdeki gelișmelere karșı, özellikle BDT ülkelerindeki iktisadi ve finansal șoklara karșı duyarlıdır (Mitra, 2010). Diğer ülkelerdeki gelișmelerin etkisini ve döviz kuru riskini belirli bir ölçüde yatsıttığı varsayılarak ve Mamonov (2013) izlenerek ABD dolarının değișim kurunun standart sapması (STDEV_FX) modele etkinsizliği etkileyen değișken olarak dahil edilmiștir. Pozitif ișaretli ve \%5 önem seviyesinde anlamlı olarak tahmin edilen ilgili katsayı döviz kurundaki dalgalanmalardaki artıș bankaların etkinliğini azaltıcı yönde etkilediğini desteklemektedir. Dıș ülkelerdeki gelișmelerden kaynaklanan döviz kurundaki dalgalanmalar bankaların kredi portfoyünün kalitesindeki bozulmalara, dolayısıyla maliyetlerindeki artıșlara ve maliyet etkinliğindeki azalmalara neden olmuștur. 
LNTA'e ait katsayının ișaretinin negatif ve \% 10 düzeyde istatistiki olarak anlamlı tahmin edilmesi büyük bankaların ölçek ve kapsam ekonomisinden yararlanarak faaliyetlerini daha az maliyetle yürütebildiklerini ve büyük bankaların daha maliyet etkin olduğunu destekleyen bulgu olarak değerlendirilebilir.

İstatistiki olarak \%5 seviyede anlamlı tahmin edilen GDP_GRW değișkenine ait katsayının ișareti iktisadi büyümenin maliyet etkinsizliği ile ters yönlü ilișkili olduğuna dair beklentilerimizi desteklemektedir. Mamonov (2013)'daki sonuçlar ile tutarlı olan bu bulgu esas alınarak Kırgızistan'da iktisadi büyüme dönemlerinde bankaların bașlıca çıktısı olan krediler ve diğer bankacılık hizmetlerine talebin artması sonucunda maliyet etkinliklerinin daha yüksek olduğu ileri sürülebilir. Diğer taraftan, iktisadi daralma dönemlerinde bankaların kredi portföyü kalitesindeki bozulmalar ve kredilerileme ile ilgili maliyetlerdeki artıșlara neden olabildiğinden GDP_GRW'nin katsayısı "șanssızlık" hipotezini belli bir ölçüde desteklemektedir.

Ișareti pozitif ve \%1 düzeyde istatistiki olarak anlamlı tahmin edilen ilgili değișkenine ait katsayının değerine göre SPREAD'in maliyet etkinsizliği üzerindeki etkisinin diğer değișkenlere göre daha az ölçüde olduğu belirtilebilir. Rekabet baskısı azaldığı, yani eksik rekabet koșullarda bankalar girdileri ve dolayısıyla maliyetlerini daha az etkinlikle gerçekleștirdiklerini öne süren "rahat yașam" hipotezini destekleyen bir bulgudur.

\section{Sonuç}

Bu çalıșmada Kırgızistan'daki bankaların finansal aracılık faaliyetinin iktisadi bir göstergesi olarak değerlendirilen maliyet etkinliğini etkileyen faktörlerin tesirinin araștırılması amaçlanmıștır. Bu amaç doğrultusunda SSY yöntemi çerçevesinde panel veri seti için Battese ve Coelli (1995)'nin Etkinsizlik Etkileri modeli uygulanmıștır. Elde edilen tahmin sonuçlarına göre, Kırgızistan'daki ticari bankaların maliyet etkinliği daha çok sermayeleșme oranı, sahiplik yapısı, kredi riski, likidite oranı ve döviz kurundaki dalgalanmalardan etkinlendiği sonucuna ulașılmıștır.

Sermayeleșme oranı, reel GSYiH'daki büyüme oranı ve bankanın aktif büyüklüğündeki artıșlar bankaların maliyet etkinliklerini artırıcı yönde etkilediğini destekleyen bulgular elde edilmiștir. Yabancı sahipliği, likidite oranı, $A B D$ doları kurunun standart sapması, kredi riski, rekabet- 
teki azalma ile maliyet etkinliği arasında ters yönlü bir ilișkinin olduğunu öne süren sonuçlara ulașılmıștır.

Kırgızistan bankacılık sektörü için belirlenen çıktıların bir veri miktarının göreceli daha az maliyetle üretilmesi için girdilerin doğru bileșenini kullanma çabasında kamu bankalarının yabancı sermayeli ve yerel özel bankalara göre daha bașarılı olduğunu destekleyen bulgular elde edilmiștir. Ulașılan sonuçlara göre, Kırgızistan'daki ticari bankaların maliyetlerinin ortalama olarak \%76.6'sı etkin kullanılmıștır.

Kırgızistan bankacılık sektörü üzerine yapılmıș önceki calıșmalardaki yöntemlerden farklı yöntemin kullanılmasıyla ölçülen maliyet etkinliği, hem sektörü denetleyen ve düzenleyen Merkez Bankası, hem de ticari bankaların yöneticileri için yararlı sonuçlar ortaya koyabilecektir. Bankacılıkta maliyet etkinliği iktisadi ve finansal açıdan sağlam bir bankacılık faaliyetinin, dolayısıyla iktisadi istikrarın ve sürüdürülebilir gelișmenin bir kaynağı olarak değerlendirilebilir.

Kar maksimizasyonu amacı güdülen bankalarda maliyetlerin așırı oranda minimize edilmesi ve daha saldırgan ve yüksek riskli kredileme polikasının izlenmesi bankacılık sektöründeki istikrarsızlığa, izleyen dönemlerde ise finansal sektördeki istikrarsızlıklara ve krizlere yol açabilir. Bu açıdan ele alındığında getiri ve risk ikilemi ile karșı karșıya kalan ticari bankaların yönetimi tarafından alınan kararlar sektörün düzenlenmesi ve denetimi açısından önemlidir.

Maliyet etkinliklerindeki değișim bankaların kredi riski alma eğilimlerini belli bir oranda yansıtabildiği esas alınarak, yüksek riskli kredileme faaliyetinde bulunan bankalardaki veya bankacılık sektöründeki muhtemel istikrarsızlığın tespitinde etkinlik skorları bir gösterge olarak kullanılabilir. Bankaların finansal aracılıktaki iktisadi maliyet etkinlikleri, bankalarin risk alma davranıșlarının düzenleyici ve gözetim otoritelerince izlenmesinde bir gösterge olarak kullanılabilir. Dolayısıyla, bu çalıșma sonuçlarının bankacılık sektörünün gözetimi ve düzenlenmesi ile ilgili politikaların geliștirilmesinde katkıda bulunabileceği beklenmektedir.

2010 yılındaki bankacılık sektöründeki krizden sonra daha etkin gözetim vasıtasıyla bankalardaki sorunların zamanında tespiti ve bununla ilgili mevzuatın geliștirilmesi gündeme gelmiștir (Jenish ve Kyrgyzbaeva, 2012:20). Erken uyarı sistemlerinin geliștirilmesi Kırgızistan bankacılık sistemi için önemli hedeflerden biri olarak belirlenmiștir. Kredilerin veri olan herhangi bir hacminin daha az maliyetle bankalar tarafından 
sağlanması maliyet etkinliğindeki artıșın sonucudur. Dolayısıyla, bankaların maliyet etkinliğindeki artıșlar, gelecek dönemlerde bankanın kredi portföyünde sorunlu kredilerin ortaya çıkmasına neden olabileceğinden dolayı düzenleyici kurum için önem tașıyabilir olabilir. Bunun tersi durumu olan maliyet etkinliğin düș̈̈k olması, gelecek dönemlerde bankaların göreceli olarak daha az kar veya daha fazla zarardan dolayı finansal durumunun zayıflaması ile ilgili bir sinyal olabilir

\section{Kaynakça}

Abdyzhaparov, A.S. (2013). Banking system development in the Kyrgyz Republic, Working papers series of the conference devoted to the 20-th anniversary of the Kyrgyz som introduction, "National currency circulation system: formation and development prospects", March 6, 2013, Bishkek, 46-52.

Aigner, D., Lovell, C. K., \& Schmidt, P. (1977). Formulation and estimation of stochastic frontier production function models, Journal of Econometrics, 6(1), 21-37.

Alantar, D. (2008). Küresel Finansal Kriz: Nedenleri ve Sonuçları Üzerine Bir Değerlendirme, Maliye Finans Yazıları Dergisi, 81.

Altunbas, Y., Carbo, S., Gardener, E.P.M., \& Molyneux, P. (2007). Examining the Relationships between Capital, Risk and Efficiency in European Banking, European Financial Management, 13(1), 49-70.

Altunbaș, Y., Gardener, E. P., Molyneux, P. \& Moore, B. (2001 a). Efficiency in European banking", European Economic Review, 45(10), 1931-1955.

Asei囚nov, D., \& Karymshakov, K. (2018). Development of the Banking System in Kyrgyzstan: An Historical Review and Current Challenges. Sosyoekonomi, 26.

Battese, G. E., \& Coelli, T. J. (1995). A model for technical inefficiency effects in a stochastic frontier production function for panel data, Empirical economics, 20(2), 325-332.

Bektenova, D. Ch., \& Atabayev, N.U. (2012). Analysis of The Monetary Base in The Conducti of Monetary Policy by The National Bank of the Kyrgyz Republic, Vestnik KRSU, 12 (1 1), 25-29.

Belotti, F., Daidone, S., llardi, G., \& Atella, V. (2013). Stochastic frontier analysis using Stata. Stata Journal, 13(4), 718-758.

Berger, A. N., \& DeYoung, R. (1997). Problem loans and cost efficiency in commercial banks. Journal of Banking \& Finance, $21(6), 849-870$.

Berger, A. N., \& Humphrey, D.B. (1992). Measurement and Efficiency Issues in Commercial Banking. in Output Measurement in the Service Sectors, Griliches, Z. (ed.), University of Chicago Press, $245-300$

Berger, A. N., Leusner, J. H., \& Mingo, J. J. (1997). The efficiency of bank branches. Journal of Monetary Economics, 40(1), 141-162. 
Berger, A.N., \& Humphrey, D.B. (1997). Efficiency of Financial Institutions: International Survey and Directions for Future Research. European Journal of Operational Research, 98, 175-212

Bogetoft, P., \& Otto, L. (2011). Benchmarking with DEA, SFA, and R. Springer, New York Dordrecht Heidelberg London.

Bonin, J. P., Hasan, I. \& Wachtel, P. (2005). Bank performance, efficiency and ownership in transition countries. Journal of Banking ve Finance, 29(1), 31-53.

Bonin, J. P., Hasan, I., \& Wachtel, P. (2005). Bank performance, efficiency and ownership in transition countries. Journal of Banking \& Finance, 29(1), 31-53.

Bonin, J. \& Wachtel, P. (2003). "Financial Sector Development in Transition Economies: Lessons from the First Decade", Financial Markets, Institutions and Instruments, V. 12, No. 1,pp. 1-66, (erișim tarihi: 06.06.2013, http://www2.econ.iastate.edu/ classes/econ370/shuffman/documents/financialmkts_trans.pdf )

Casu, B., \& Girardone, C. (2009). Does competition lead to efficiency? The case of EU commercial banks. The Case of EU Commercial Banks", Discussion Paper No. 0701, January 15, 2009.

Chen, M. J., Chiu, Y. H., Jan, C., Chen, Y. C. \& Liu, H. H. (2015). Efficiency and Risk in Commercial Banks-Hybrid DEA Estimation. Global Economic Review, 44(3), 335352.

Cheng, H., Lu, Y. C., \& Mukashev, U. (2013). Productivity of the banking sector: A case study in Kyrgyz Republic. In Innovative Computing Technology (INTECH), 2013 Third International Conference on, IEEE, 173-180.

Coleman, B. E., Goffe, V., Perolli, B., Usupova, M., Castillo, L. V., Holzhacker, H. \& Kappeler, A. (2012). Banking in the Eastern neighbours and Central Asia: Challenges and opportunities. Regional Studies and Roundtables, European Investment Bank (EIB), 56-61.

Delis, M. D., Molyneux, P. \& Pasiouras, F. (2011). Regulations and productivity growth in banking: Evidence from transition economies.Journal of Money, Credit and Banking, 43(4), 735-764.

Dialilov, K. \& Piesse, J. (2014).The Determinants of Bank Efficiency in Central Asia. Corporate Ownership ve Control, 12(1), 656-670.

Drakos, K. (2003). Assessing the success of reform in transition banking 10 years later: an interest margins analysis.Journal of Policy Modeling, 25, 309-3 17.

Duygun, M., Sena, V. \& Shaban, M. (2014). Trademarking status and economic efficiency among commercial banks: Some evidence for the UK. Journal of Banking ve Finance, 49, 506-514E

Ferhi, A. \& Chkoundali, R. (2015). Credit Risk and Efficiency: Comparative Study between Islamic and Conventional Banks during the Current Crises. Journal of Behavioural Economics, Finance, Entrepreneurship, Accounting and Transport, 3(1), 47-56.

Ferrier, G. D., \& Lovell, C. K. (1990). Measuring cost efficiency in banking: econometric and linear programming evidence. Journal of econometrics, 46(1), 229-245. 
Fiordelisi, F., Marques-lbanez, D. \& Molyneux, P. (201 1). Efficiency and risk in European banking. Journal of Banking and Finance, 35(5), 1315-1326.

Fries, S. \& Taci, A. (2005). Cost efficiency of banks in transition: Evidence from 289 banks in 15 post-communist countries. Journal of Banking ve Finance, 29(1), 55-81.

Glass, A. J., Kenjegalieva, K. \& Weyman-Jones, T. (2014). Bank performance and the financial crisis: evidence from Kazakhstan. Applied Financial Economics, 24(2), 121-138.

Goddard, J., Molyneux, P., \& Williams, J. (2014). Dealing with cross-firm heterogeneity in bank efficiency estimates: Some evidence from Latin America. Journal of Banking ve Finance, 40, 130-142.

Gorton, G. \&Winton, A. (1998). Banking in Transition Economies: Does Efficiency Require Instability?. Journal of Money, Credit and Banking, Vol. 30, No. 3, Part 2: Comparative Financial Systems, pp. 621-650.

Greene, W.H. (2005a). Fixed and Random Effects in Stochastic Frontier Models. Journal of Productivity Analysis, 23, 7-32.

Greene, W.H. (2005b). Reconsidering Heterogeneity in Panel Data Estimators of The Stochastic Frontier Model.Journal of Economics, 126, 269-303.

Grigorian, D. \& Manole, V. (2002). Determinants of commercial bank performance in transition: An application of data envelopment analysis. World Bank Policy Research Working Paper, No: 2850.

Hassan, M. S. M. (2008). Financial liberalization, privatization, and productivity in banking: The experience of two emerging economies. Published PhD Thesis, University of Leicester, Leicester.

Huang, J., Chen, J. \& Yin, Z. (2014). A Network DEA Model with Super Efficiency and Undesirable Outputs: An Application to Bank Efficiency in China. Mathematical Problems in Engineering, 2014.

Isik, I., \& Hassan, M. K. (2002). Cost and profit efficiency of the Turkish banking industry: An empirical investigation. Financial Review, 37(2), 257-279.

Jarraya, B. (2014). Parametric Meta-Technology Frameworks to Study Technical Efficiency and Macro-Economic Effects in the European Banking System. Contemporary Economics, 8(1), 73-88.

Jenish, N. \& Kyrgyzbaeva, A. (2012). On the Possibility of Inflation Targeting in Kyrgyzstan. No. 12/10e, EERC Research Network, Russia and CIS.

Jondrow, J., Lovell, C. K., Materov, I. S. \& Schmidt, P. (1982). On the estimation of technical inefficiency in the stochastic frontier production function model. Journal of econometrics, 19(2-3), 233-238.

Kasman, A. \& Carvallo, O. (2013). Efficiency and Risk in Latin American Banking: Explaining Resilience. Emerging Markets Finance and Trade, 49(2), 105-130.

Kasman, A. \& Yildirim, C. (2006). Cost and profit efficiencies in transition banking: the case of new EU members. Applied Economics, 38(9), $1079-1090$.

Kasman, A. (2003). Banking Efficiency During the Financial Crisis Period", ISE Review, 7, 83-97. 
Keleș, İ. (201 1). Kırgız Bankacılık Sisteminde Etkinliğin Veri Zarflama Analiziyle Ölçülmesi. Doktora Tezi, Kırgızistan-Türkiye Manas Üniversitesi, Sosyal Bilimler Enstitüsü, İșletme Anabilim Dalı

Kenjegalieva, K.A. \& Simper, R. \& Weyman-Jones, T.G. (2009). Efficiency of transition banks: inter-country banking industry trends. Applied Financial Economics, 19(19), 1531-1546.

Kloc, K. (2001). Banking systems of Ukraine, Georgia and Kyrgyzstan and the problem of the banking crisis. Center for Social and Economic Research (CASE), 236.

Koetter, M. \& Porath, D. (2007). Efficient, profitable and safe banking: an oxymoron? Evidence from a panel VAR approach. Discussion Paper No. 2007/02, Series 2: Banking and Financial Supervision. Deutsche Bundesbank, Research Centre.

Koetter, M. (2006). Measurement matters-alternative input price proxies for bank efficiency analyses. Journal of Financial Services Research, 30(2), 199-227.

Kök, R., \& Deliktaș, E. (2003). Endüstri İktisadında Verimlilik Ölçme ve Strateji Geliștirme Teknikleri. Dokuz Eylül Üniversitesi İ̈BF Yayını, İzmir.

Košak, M., Zajc, P. \& Zorić, J. (2009). Bank efficiency differences in the new EU member states. Baltic Journal of Economics, 9(2), 67-89.

Kumar, S. \& Gulati, R. (2014). Deregulation and Efficiency of Indian Banks, India Studies in Business and Economics, Springer İndia, 49-131.

Mamonov, M., Pestova, A. \& Solntsev, O. (2013). Estimation of Systemic Effects from Tightening of Prudential Regulation of the Banking Sector: Results of a Stress Test. Problems of Economic Transition, 56(7), 37-74.

Mamonov, M. (2013). Bad management, skimping, or both? The relationship between cost efficiency and loan quality in Russian banks. Working Paper, No. BRP 19/ FE/2013, NRU, Higher School of Economics

Maslak, N.G. \& Buryak, A.V. (Маслак, Н. Г. \& Буряк, А. В.) (2009). Методические подходы к оценке эффективности деятельности банка. Бизнес Информ, 12, 2, 187-191 (erișim tarihi: 19.04.2016, http://dspace.uabs.edu.ua/bitstream/123456789/2301/1/Buriak_001.pdf)

Matthews, K., Xiao, Z. \& Zhang, X. (2009). Rational cost inefficiency in Chinese banks . Cardiff University, Cardiff Business School, Economics Section Working Papers (No. E2009/13).

Meeusen, W. \& van Den Broeck, J. (1977). Efficiency estimation from Cobb-Douglas production functions with composed error. International Economic Review, 435444.

Mitra, P. K. (2010). The Impact of Global Financial Crisis and Policy Responses The Caucasus, Central Asia and Mongolia. Global Journal of Emerging Market Economies, 2(2), 189-230.

National Bank of the Kyrgyz Republic (2018), Annual Report of the National Bank of the Kyrgyz Republic for 2017, < https://www.nbkr.kg/ DOC/04052018/000000000049877.pdf>, 27.02.2019. 
Nigmonov, A. (2010). Bank Performance and Efficiency in Uzbekistan. Eurasian Journal of Business and Economics, 3(5), 1-25.

Parmeter, C. F. \& Kumbhakar, S. C. (2014). Efficiency analysis: a primer on recent advances. Foundations and Trends in Econometrics, 7(3-4), 191-385.

Pilyarskyy, A. I., Matsiv, Y. I. \& Vovchak, O.D. (2012). Cost Efficiency Of Ukrainian Banks. Does It Make Difference? Warsaw School of Information Technology ve Systems Research Institute

Quagliariello, M. (2007). Banks' riskiness over the business cycle: a panel analysis on Italian intermediaries. Applied Financial Economics, 17(2), 119-138.

Radic, N., Fiordelisis, F. \& Girardone, C. (2012). Efficiency and Risk-Taking in Pre-Crisis Investment Banks. Journal of Financial Services Research, 41, 81-101.

Ruziev, K. \& Majidov, T. (2013). Differing Effects of the Global Financial Crisis on the Central Asian Countries: Kazakhstan, the Kyrgyz Republic and Uzbekistan. EuropeAsia Studies, Vol. 65, No. 4, June 2013, pp. 682-716

Schmidt, P. (201 1). One-step and two-step estimation in SFA models. Journal of Productivity Analysis, 36(2), 201-203.

Sealey, Jr.C.W. \& Lindley, J.T. (1977). Inputs, Outputs, and Theory of Production Cost at Depository Financial İnstitutions. Journal of Finance, 32, 1251-1266.

Seven, Ü., \& Yetkiner, H. (2016). Financial intermediation and economic growth: Does income matter?. Economic Systems, 40(1), 39-58.

Shen, Z., Liao, H. \& Weyman-Jones, T. (2009). Cost efficiency analysis in banking industries of ten Asian countries and regions). Journal of Chinese Economic and Business Studies, 7(2), 199-218.

Sherman, J. D. \& Gold, F. (1985). Bank Branch Operating Efficiency: Evaluation With Data Envelopment Analysis. Journal of Banking and Finance, 9, 297-316

Spulbăr, C., Nițoi, M. \& Anghel, I. (2015). Efficiency in Cooperative Banks and Savings Banks: A Stochastic Frontier Approach. Romanian Journal of Economic Forecasting, 18(1), 5-21.

Staikouras, C., Mamatzakis, E. \& Koutsomanoli-Filippaki, A. (2008). Cost efficiency of the banking industry in the South Eastern European region. Journal of International Financial Markets, Institutions and Money, 18(5), 483-497.

Styrin, K. (2005). What Explains Differences in Efficiency Across Russian Banks?. No. 01-258e-1, EERC Research Network, Russia and CIS.

Sufian, F. \& Habibullah, M. S. (2012). Developments in the efficiency of the Malaysian banking sector: the impacts of financial disruptions and exchange rate regimes. Progress in Development Studies, 12(1), 19-46.

Tente, S.D. (2010). Bank Efficiency Estimation: Methodology and the Problem of Adequation. Faculty of Economics, University of Münster, Inaugural Dissertation for The Academic Degree Doctor of Economic Sciences

Wang, H. J., \& Schmidt, P. (2002). One-step and two-step estimation of the effects of exogenous variables on technical efficiency levels. Journal of Productivity Analysis, 18(2), 129-144. 
Williams, J., (2004). Determining Management Behaviour in European Banking. Journal of Banking and Finance, 28, 2427-2460.

$\mathrm{Xu}, \mathrm{H}$. (2016). Financial Intermediation and Economic Growth in China: New Evidence from Panel Data. Emerging Markets Finance and Trade, 52(3), 724-732. 